DOI: 10.35757/RPN.2015.23.01

\title{
ODSZEDŁ PROFESOR JERZY HOLZER
}

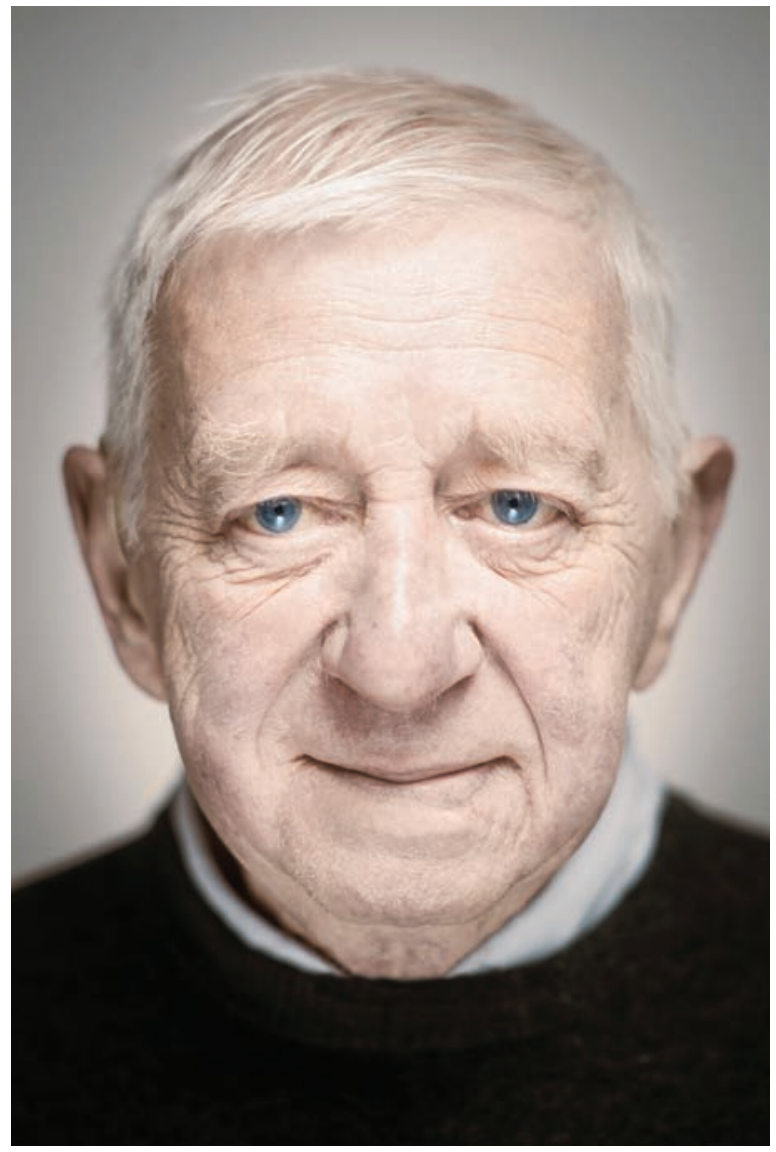

Fot. Adam Tuchliński, Newsweek Polska

W dniu 13 stycznia 2015 roku zmarł w Warszawie w wieku 84 lat profesor Jerzy Holzer. Pożegnaliśmy Go 20 stycznia na Starych Powązkach. 
Już wcześniej odeszło pokolenie historyków polskich ukształtowanych przed drugą wojną światową. Jerzy Holzer należał do generacji kolejnej, do coraz bardziej nielicznych polskich historyków, młodszych wprawdzie, ale pamiętających z własnego doświadczenia drugą wojnę światowa pierwsze najtrudniejsze dla społeczeństwa polskiego lata komunizmu i niełatwe początki polsko-niemieckiego pojednania. Ze względu na problematykę niemiecką, tak istotną w badaniach i aktywności Jerzego Holzera, wymienić można tutaj wielu uznanych badaczy z nią związanych, którzy odeszli w ostatnich latach: Marian Biskup, Jerzy Krasuski, Gerard Labuda, Czesław Łuczak, Czesław Madajczyk, Karol Jonca, Zygmunt Mańkowski, Franciszek Ryszka, Tomasz Strzembosz, Maria Wawrykowa, Marian Wojciechowski, Wojciech Wrzesiński.

Profesor Holzer, rocznik 1930, opisał swoje przeżycia w czasie ukrywania się $\mathrm{w}$ Warszawie $\mathrm{w}$ czasie drugiej wojny światowej $\mathrm{w}$ swoich wspomnieniach Historyk w trybach historii wydanych niedawno, w 2013 roku, przez Znak. Jak napisał Adam Michnik, „Był ważnym i uważnym świadkiem swojej skomplikowanej epoki i towarzyszył jej na wszystkich zakrętach dziejowych"1. Swoją drogę naukową jako historyk zaczynał na Uniwersytecie Warszawskim, studiując w pierwszej połowie lat pięćdziesiątych: w latach stalinowskich, ale zarazem w czasie, gdy stalinizm nie przeniknął jeszcze do środowiska uniwersyteckiego. Po napisaniu pracy magisterskiej u prof. Żanny Kormanowej pozostał z Uniwersytetem Warszawskim związany przez prawie pół wieku, jako pracownik Instytutu Historycznego. Po bolesnych przejściach okresu okupacji uległ zauroczeniu komunizmem jako ustrojem sprawiedliwości społecznej, co także odpowiadało Jego lewicowym przekonaniom. Wstąpił do Związku Młodzieży Polskiej, następnie do Polskiej Zjednoczonej Partii Robotniczej, uczestniczył w partyjnych dyskusjach na Uniwersytecie, był doktorantem w Instytucie Kształcenia Kadr Naukowych przy KC PZPR.

Jego zainteresowania badawcze skoncentrowane były wówczas wokół pierwszej wojny światowej, okresu międzywojennego, najnowszej historii Niemiec i relacji polsko-niemieckich. W tym pierwszym okresie

1 A. Michnik, Był z nami w gorszych czasach. Pożegnanie Jerzego Holzera, "Gazeta Wyborcza", 21 stycznia 2015. 
badań powstała napisana razem z Janem Molendą Polska w I wojnie światowej, wydana w 1973 roku. Druga, po pracy Janusza Pajewskiego, próba spojrzenia na wydarzenia poprzedzające odbudowę państwa polskiego. Szczególne znaczenie miały badania Jerzego Holzera nad partiami politycznymi w II RP, których wynikiem były Polska Partia Socjalistyczna w latach 1917-1919 i Mozaika polityczna II Rzeczypospolitej. O Mozaice tak mówił Andrzej Friszke podczas obchodów 80-lecia profesora Holzera: „Jest to książka, która w moim przekonaniu do tej pory zachowuje wartość przez kompetentne omówienie bogactwa życia politycznego, ideologii, struktur organizacyjnych. Nie ma niczego porównywalnego do dnia dzisiejszego" ${ }^{2}$. Równocześnie widoczne było zainteresowanie sprawami niemieckimi, a książka z 1970 roku Kryzys polityczny w Niemczech 1928-1930. Partie i masy ukazała się w tym samym roku w języku niemieckim.

Ponieważ bliższa Mu była ideologia lewicy demokratycznej, Profesor odchodził z czasem od komunizmu w stronę wartości demokratycznych. Na początku lat sześćdziesiątych uwierzył jeszcze, że jego patriotycznym obowiązkiem jest pomaganie państwu wobec zagrożenia zachodnioniemieckiego. Płacił za to wysoką cenę po 1989 roku. W drugiej połowie lat sześćdziesiątych nie akceptował już kampanii władz wymierzonej przeciwko uczestnikom Marca '68, nagonki na Leszka Kołakowskiego, odrzucał niedemokratyczne mechanizmy działania Polskiej Zjednoczonej Partii Robotniczej czy też polski udział w stłumieniu praskiej wiosny. $W$ wielu wspomnieniach powraca ocena, że był pozytywista, starającym się chronić naukę przed polityka, ale niegotowym do ustępstw i sformułowań w swoich pracach, za które po latach musiałby się wstydzić. Cenione były prowadzone przez Niego zajęcia dydaktyczne na Uniwersytecie Warszawskim, w których ważną rolę odgrywała tematyka niemiecka.

W końcu lat siedemdziesiątych odszedł z PZPR, włączył się w działalność opozycji, współpracował z Komitetem Obrony Robotników, angażował w Polskim Porozumieniu Niepodległościowym, pisywał do wydawnictw ukazujących się w drugim obiegu, współorganizował

2 Jubileusz osiemdziesięciolecia Profesora Jerzego Holzera, "Rocznik Polsko-Niemiecki” 2011, t. 19, s. 9-40, tutaj s. 29-30. 
niezależne dyskusje o historii najnowszej i zdecydował się wystąpić z PZPR. W 1980 roku należał do organizatorów „Solidarności” na Uniwersytecie Warszawskim, był też jej doradcą do spraw niemieckich, aby po 13 grudnia 1981 roku znaleźć się wśród internowanych, w Jaworze koło Drawska, w towarzystwie m.in. Adama Michnika, Tadeusza Mazowieckiego, Bronisława Geremka i Bronisława Komorowskiego.

Coraz bardziej interesowała Go historia najnowsza i syntetyczne ujęcia, przesuwał się w stronę politologii, już wcześniej włączał do swoich badań elementy analizy socjologicznej, aczkolwiek do końca pozostał nade wszystko historykiem. W 1983 roku wydał Solidarność 1980-1981. Geneza $i$ historia, która ukazała się także w wersji niemieckiej. Udało $\mathrm{Mu}$ się przy jej pisaniu połączyć wiedzę i zaangażowanie uczestnika z dystansem i warsztatem historyka. A wiedza i zaangażowanie były tym większe, że - jak sam wspominał - życie zetknęło go z wielu ciekawymi ludźmi: Bronisławem Geremkiem, Benedyktem Zientara, Antonim Mączakiem, Henrykiem Samsonowiczem, Witoldem Kula, Leszkiem Kołakowskim, Leszkiem Balcerowiczem, Tadeuszem Mazowieckim itd.

Logiczną konsekwencją Jego zainteresowań i zaangażowania była decyzja o włączeniu się po przełomie 1989 roku do inicjatywy tworzenia Instytutu Studiów Politycznych Polskiej Akademii Nauk jako nowego, interdyscyplinarnego ośrodka badań naukowych, którego był w latach 2000-2004 dyrektorem. Kierował w nim od powstania w 1990 roku do 2005 roku Zakładem Studiów nad Niemcami, założył „Rocznik Polsko-Niemiecki”. Zakład ten i wydawany przezeń rocznik miały ugruntować badania niemcoznawcze w Warszawie, które od lat osiemdziesiątych straciły wcześniejszą dynamikę. Punkt ciężkości badań stanowić miała historyczno-politologiczna analiza sytuacji w Niemczech, porównanie polskich i niemieckich doświadczeń w przezwyciężaniu systemów totalitarnych i budowie systemów demokratycznych oraz współczesne stosunki polsko-niemieckie. Pierwszy numer „Rocznika” otwierał artykuł podsumowujący wiele wcześniejszych doświadczeń Jerzego Holzera w PRL: Uraz, nacjonalizm, manipulacja. Kwestia niemiecka w komunistycznej Polsce.

Interesowała Go najnowsza historia powszechna i nie sposób w tym miejscu nie przypomnieć Jego książki o Komunizmie w Europie. Nie zre- 
zygnował z dydaktyki, nauczając w Collegium Civitas. Trudno przecenić jednakże znaczenie, jakie Jerzy Holzer miał dla stosunków polsko-niemieckich, budowania kontaktów między polską i niemiecką nauką historyczną. Także tych prywatnych, bo przyjaźń łączyła Go z wybitnymi niemieckimi naukowcami - Helmutem Wagnerem, Heinrichem-Augustem Winklerem czy też Gesine Schwan.

Do Niemiec Zachodnich wyjeżdżał już od lat sześćdziesiątych na pobyty badawcze - do Moguncji, Fryburga Bryzgowijskiego i Berlina. Przez wiele lat uczestniczył w pracach Polsko-Niemieckiej Komisji Podręcznikowej, będąc od 2014 roku jej honorowym członkiem. Przewodniczył Forum Polsko-Niemieckiemu w okresie 1989-1994, czyli w pierwszych latach po przełomie, gdy odgrywało ono szczególną rolę. Był członkiem zarządu Fundacji Współpracy Polsko-Niemieckiej. Zasiadał przez dwie kadencje w Radzie Naukowej utworzonego w 1993 roku Niemieckiego Instytutu Historycznego. Popierał utworzenie w Berlinie placówki Polskiej Akademii Nauk zajmującej się badaniami historycznymi. Najpierw była to Stacja Naukowa PAN, a następnie Centrum Badań Historycznych, z którym do końca współpracował. Był współautorem realizowanego przez Centrum dużego projektu „Polsko-niemieckie miejsca pamięci”, teksty Jego autorstwa ukazywały się w wydawnictwie o polsko-niemieckich miejscach pamięci, wydanych pod redakcją Roberta Traby i Hansa Henninga Hahna.

Wielu zmian dokonywanych w polskiej nauce nie akceptował, uważając je za sprzeczne z misją badacza, który w pogłębionych opracowaniach winien starać się zrozumieć epokę, a nie kolekcjonować punkty, rozpraszając się na pozbawione większego znaczenia referaty i artykuły. Te celne krytyczne zastrzeżenia nie zmniejszały Jego aktywności. W ostatnich latach, gdy postępujące problemy ze słuchem uniemożliwiły Mu udział w konferencjach i dyskusjach, starał się dokonać podsumowania swoich badań w syntetycznych ujęciach europejskiej historii najnowszej. W 2005 roku ukazała się Europejska tragedia XX wieku. II wojna światowa, trzy lata później Europa wojen 1914-1945, a w 2012 roku Europa zimnej wojny, wyróżniona nagrodą im. Jana Długosza za najlepszą książkę humanistyczną. Są to prace oparte na ogromnej erudycji, ale zarazem odmienne od tych z lat wcześniejszych: bardziej 


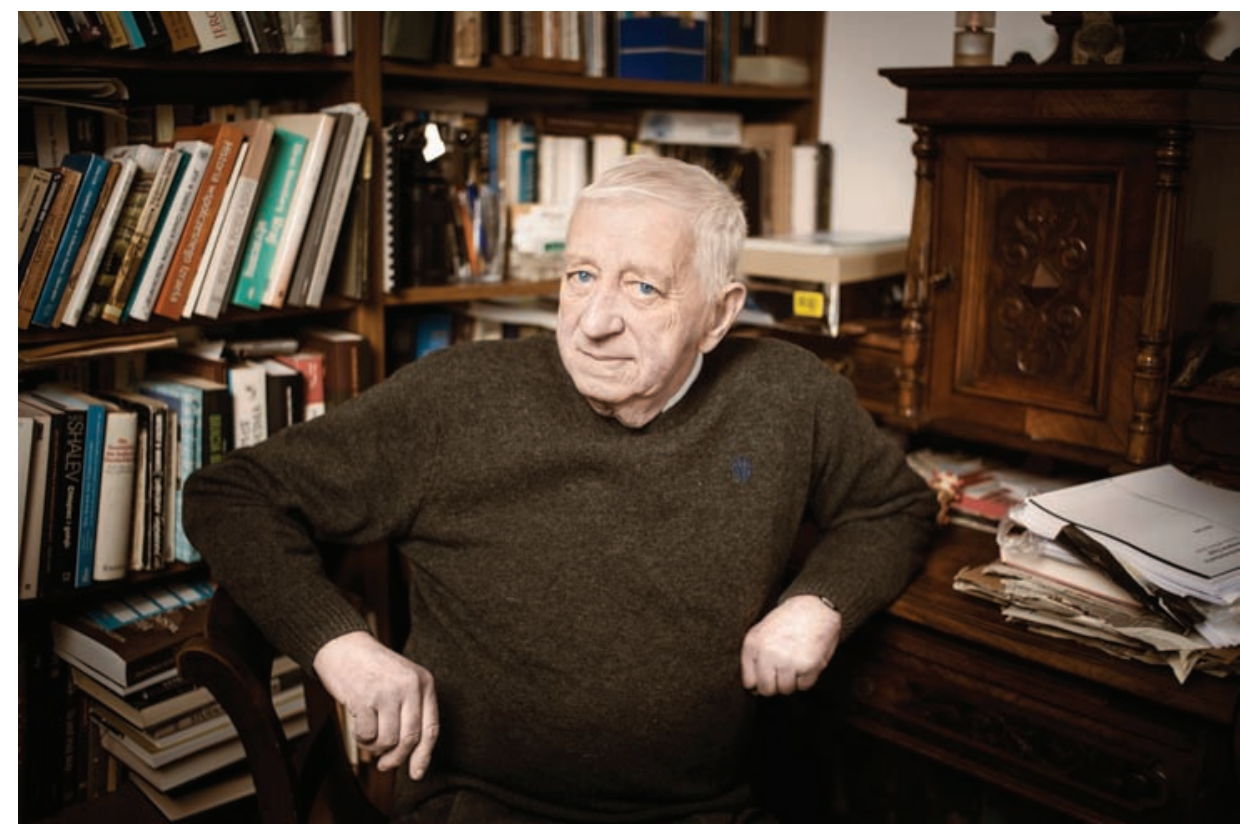

Fot. Adam Tuchliński, Newsweek Polska

syntetyczne, ale chyba i bardziej emocjonalne. Naznaczone przekonaniem, że: „Wymierają już ci, którzy świadomie przeżyli owe lata, a i tak dystans zaciera osobiste wspomnienia. Dla potomnych II wojna światowa zdawać się może równie odległa, a do pewnego stopnia egzotyczna jak wojny Greków z Persami, najazdy Hunów, wyprawy krzyżowe, wojna trzydziestoletnia czy podboje Napoleona"3. Ale także nadzieja, że Europa przezwyciężyła kryzys XX wieku i może optymistycznie patrzeć w przyszłość 4 .

Żegnamy wybitnego naukowca i humanistę,

Piotr Madajczyk, Wanda Jarząbek, Eugeniusz Cezary Król, Robert Traba, Joanna Szymoniczek, Paweł Popieliński, Piotr Andrzejewski

3 J. Holzer, Europejska tragedia XX wieku. II wojna światowa, Warszawa 2005.

4 Por. wstęp w: J. Holzer, Europa wojen 1914-1945, Warszawa 2008. 